University of Nebraska - Lincoln

DigitalCommons@University of Nebraska - Lincoln

U.S. Navy Research

U.S. Department of Defense

2002

\title{
Epidemic Malaria in the Menoreh Hills of Central Java
}

Mazie J. Barcus

U.S. Naval Medical Research Unit \#2

Ferdinand Laihad

M. Sururi

Priyanto Sismadi

Harijani Marwoto

See next page for additional authors

Follow this and additional works at: https://digitalcommons.unl.edu/usnavyresearch

Barcus, Mazie J.; Laihad, Ferdinand; Sururi, M.; Sismadi, Priyanto; Marwoto, Harijani; Bangs, Michael J.; and Baird, J. Kevin, "Epidemic Malaria in the Menoreh Hills of Central Java" (2002). U.S. Navy Research. 52.

https://digitalcommons.unl.edu/usnavyresearch/52

This Article is brought to you for free and open access by the U.S. Department of Defense at DigitalCommons@University of Nebraska - Lincoln. It has been accepted for inclusion in U.S. Navy Research by an authorized administrator of DigitalCommons@University of Nebraska - Lincoln. 


\section{Authors}

Mazie J. Barcus, Ferdinand Laihad, M. Sururi, Priyanto Sismadi, Harijani Marwoto, Michael J. Bangs, and J. Kevin Baird 


\title{
EPIDEMIC MALARIA IN THE MENOREH HILLS OF CENTRAL JAVA
}

\author{
MAZIE J. BARCUS, FERDINAND LAIHAD, M. SURURI, PRIYANTO SISMADI, HARIJANI MARWOTO, \\ MICHAEL J. BANGS, AND J. KEVIN BAIRD \\ U.S. Naval Medical Research Unit \#2, Jakarta, Indonesia; Directorate of Vector-borne Disease Control, Ministry of Health, Jakarta, \\ Indonesia; District Health Service, Purworejo, Central Java, Indonesia; Center for Communicable Disease Research, \\ Jakarta, Indonesia
}

\begin{abstract}
After more than 50 years of effective management, resurgent malaria threatens residents in the Menoreh Hills and the foothills of the Dieng Plateau of Central Java, Indonesia. The Dieng Plateau dominates the highland center of Central Java. The steep Menoreh Hills, surrounded by rice paddy habitats, cover approximately $500 \mathrm{~km}^{2}$ with no peaks greater than $1,000 \mathrm{~m}$. We studied epidemic malaria in Purworejo district, one of the three districts containing the Menoreh Hills. Between 1986 and 1995, the annual parasite incidence (API) in Purworejo ranged from 2 to 11 cases per 1,000 residents per year and was typically approximately 5 per 1,000. In 2000 the API was 44.5. This sharp increase was confined to subdistricts in and around the Menoreh Hills and Dieng Plateau foothills. The primary vectors of malaria, those favoring steep, forested hillsides on Java, were Anopheles maculatus and Anopheles balabacensis. Deterioration of vector control activity, followed by a severe economic downturn in 1997, may explain the epidemic. Malaria in the Menoreh Hills and lower Dieng Plateau threatens surrounding areas of rice paddy inhabited by Anopheles aconitus as well as a nearby coastal habitat where the even more efficient vector Anopheles sundaicus occurs in abundance. Most of the 130 million people living on Java never experienced the hyper- and holoendemic malaria that occurred throughout most of the island before the effective DDT spraying and chloroquine treatment campaigns of the 1950s. Reintroduced endemic malaria threatens the island of Java.
\end{abstract}

\section{INTRODUCTION}

A global resurgence of malaria began around 1970 and continues today with gaining momentum. ${ }^{1-4}$ Manifold causes explain the phenomenon, but the proliferation of resistance to standard antimalarial drugs and the social reluctance to apply residual insecticides represent dominant factors. ${ }^{5}$ DDT and chloroquine eradicated or controlled malaria across vast reaches of the globe, and the loss of these weapons without practical alternatives has left those areas susceptible to encroachment and reestablishment of endemic malaria. Epidemics of malaria in Armenia, Tajikstan, Turkey, Peru, Korea, highland zones in Africa and New Guinea, and many other sites during the 1990s represent examples. ${ }^{6-10}$ Outbreaks of malaria in the United States ${ }^{11}$ illustrate the potential of malaria to reach back into almost any setting from which it had been eradicated. The most worrisome aspect of the encroachment of endemic malaria is the lack of infrastructure and implements with which to regain control.

The islands of Java and Bali in the Indonesian archipelago (Figure 1) represent the most remarkable and long-lived examples of the success possible with sustained residual insecticide spraying programs. In the early 1950s, the fledgling Republic of Indonesia worked with the U.S. International Cooperation Agency (U.S. Agency for International Development predecessor) to organize and implement an aggressive household DDT spraying program. Up to that time, hyper- to holoendemic malaria occurred through most of Java and Bali. Into the 19th century, Java had the reputation, like the Gold Coast in West Africa, of being a malaria graveyard for Europeans. ${ }^{12}$ Reported spleen rates at each of eight sites covering the length of Java sampled in 1925 exceeded $80 \%{ }^{13}$ As late as 1949, holoendemic malaria was documented near Jakarta on the north coast. ${ }^{14}$ In 1953 the slide-positive rate for Central Java was $24 \% .^{15}$ Just 6 years after initiating a control program emphasizing DDT spraying, the slidepositive rate fell to $0.7 \% .{ }^{15}$ Between 1963 and 1986, the annual parasite incidence (API; infections per 1,000 residents per year) on Java and Bali ranged between 0.1 and 4.4, aver- aging 1.2. During 21 of the 24 years in this period, the slidepositive rate was below $2 \%$; typically, more than 7 million slides were examined each year. ${ }^{15}$ The Republic of Indonesia abandoned DDT spraying in the late 1980s; most stocks were exhausted by the early 1990s. ${ }^{16}$ Spraying of residual insecticides continued but with relatively expensive pyrethroids and carbamates. Nonetheless, robust economic conditions in Indonesia during the early 1990s permitted household coverage with residual insecticides in areas considered at risk.

From 1950 to 1990 endemic malaria was virtually eradicated from West Java, East Java, and most of Bali. Even in malarious Central Java, most areas were successfully cleared. Data from 1993 illustrate the focal nature of persistent endemic malaria in Central Java. ${ }^{17}$ Among the 3.1 million people living in the districts of Purworejo, Jepara, Pekalongan, and Banjarnegara, 12,512 cases were reported (API = 4.0). In contrast, among the 26.6 million residents of the 31 other districts in the province, just 1,991 cases were reported $(\mathrm{API}=0.01)$. In other words, $86 \%$ of cases occurred in districts representing just $10 \%$ of the population of Central Java. ${ }^{17}$ Data from the neighboring Special Area of Yogyakarta in the same year even more dramatically illustrate this point: the 40,246 residents of Kokap subdistrict in Kulonprogo district constituted $1.3 \%$ of the total population but $85 \%$ of malaria cases $(2,516)$. Moreover, $92 \%$ of reported cases in Kokap came from two areas: Kalirejo and Hargotirto. These areas constituted the portion of Kokap subdistrict in Kulonprogo district lying in the Menoreh Hills, adjacent to Purworejo (Figure 2). Foci of chronic hypoendemicity in Central Java have long threatened to seed the reintroduction of endemic malaria on Java.

This report describes realization of that threat with an epidemic of malaria in the Menoreh Hills of southeastern Central Java. The explosive increase in risk of infection in those hills and in the nearby foothills of the Dieng Plateau largely accounts for the rise in API for all of Java and Bali from approximately 0.1 to about 0.8 between 1995 and 2000 (Figure 3 ). The epidemic serves as a focal point for examining the encroachment of malaria back into areas where it had been 


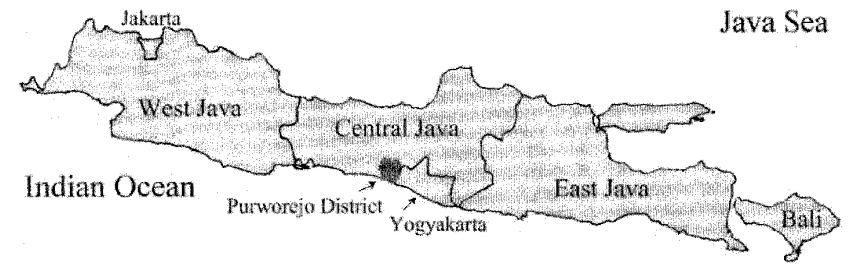

Figure 1. Map of Java and Bali showing location of Central Java province and Purworejo district.

brought under control. We conducted a retrospective analysis of malaria surveillance data reported to the Sub-Directorate for Malaria Control in the Indonesian Ministry of Health to examine the epidemic in the Menoreh Hills.

\section{MATERIALS AND METHODS}

Site. Figure 1 shows the location of Purworejo district on Java. Figure 2 illustrates the topography of the region and the location of the Menoreh Hills within eastern Purworejo and western Kulonprogo districts. The northern tier of Purworejo includes some of the foothills of the relatively enormous $\mathrm{Di}$ eng Plateau. The southern tier of Purworejo is a narrow coastal zone of nipah palm marsh and fish ponds. Between the coast and the hills, rice cultivation dominates a broad low plain. The Menoreh Hills in the northeast and the foothills of the Dieng Plateau to the northwest constitute the forested hill regions (Figure 4). The hills rise to approximately $900 \mathrm{~m}$. The principal cash crop in the hills is clove, but there is also extensive cultivation of bamboo, coffee, teak, balsam, coconut, salak, and subsistence fruits such as banana and papaya. Many narrow valleys contain terraced rice paddy. Abundant steep, rocky streams drain the heavy rainfall $(4,000 \mathrm{~mm} /$ year $)$

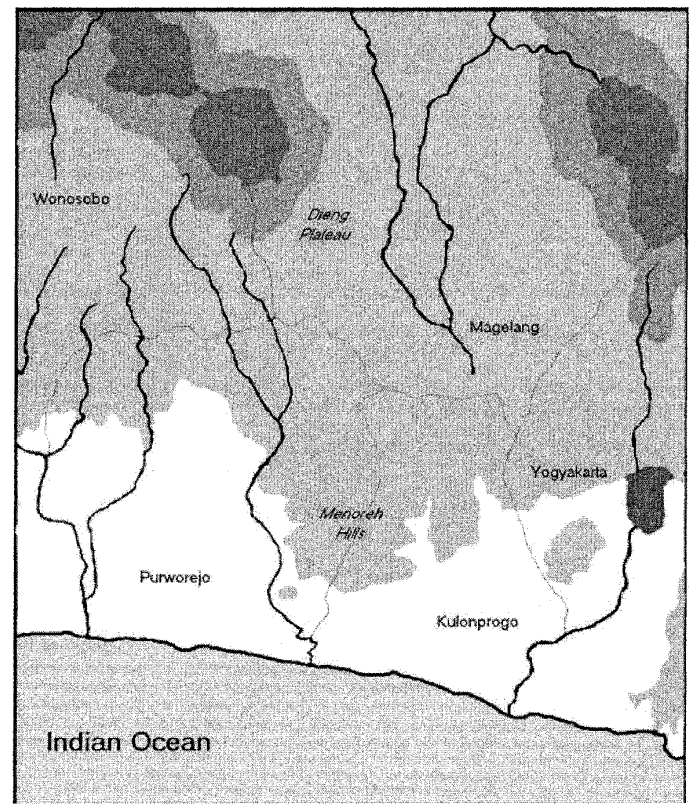

\section{- River _.... District border}

FIGURE 2. Topographic map of the region shows the Menoreh Hills and foothills of the Dieng Plateau.

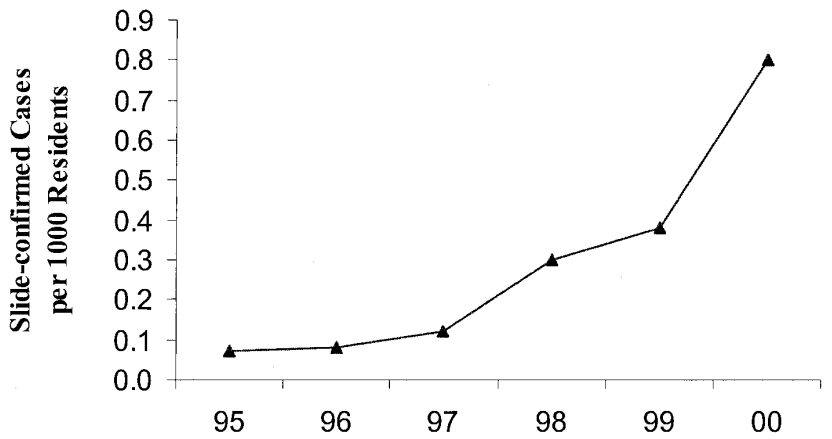

FIGURE 3. Annual parasite incidence (reported cases/1,000 residents/year) for Java and Bali (Ministry of Health, Republic of Indonesia).

occurring predominantly from October to April. As rains diminish, the stream flows recede, leaving pools along the rocky streambeds. The average annual minimum temperature is $23^{\circ} \mathrm{C}$ and the maximum $36^{\circ} \mathrm{C}$. The relative humidity varies from $50 \%$ to $90 \%$, tending to be higher on the coast and lower inland.

Anopheline vectors. Anopheles maculatus and Anopheles balabacensis play a major role in the transmission of malaria among the steep, forested hills of Central Java. ${ }^{18,19}$ These vectors appear to be primarily anthropophilic and exophilic in behavior, but detailed studies are lacking. A. balabacensis generally prefers small, stagnant water habitats that are well shaded and lacking vegetation. Suitable sites are often associated with seepage springs, pools, and small ground depressions such as footprints. A. maculatus prefers calm, clear water that collects in drying rocky streambeds and sun-exposed seepages. It may also be found along the still margins of slower running rivers and irrigation ditches. A. balabacensis is more common during the wet periods (October-April) of the year, whereas $A$. maculatus shows population increases during the drier months.

Malaria transmission in Central Java is perennial but normally peaks during the dry season (May-September), suggesting that the most important vector species breed in habitats that become relatively plentiful during this period. The abundance of drying rocky streambeds ideal for $A$. maculatus appears to correlate with risk of malaria. Sporozoites of plasmodia (microscopic identification) have been recovered in

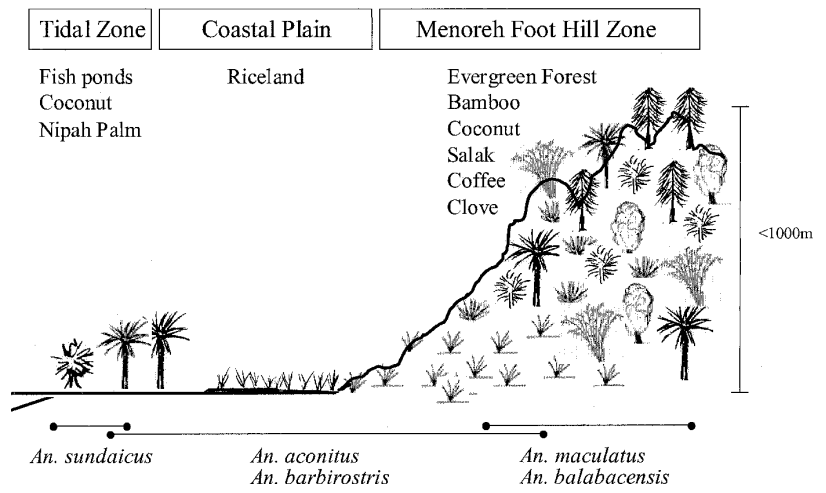

FIGURE 4. Schematic representation of the three principal habitats of Purworejo district and the important anopheline mosquitoes that occur in each. 
both $A$. maculatus and $A$. balabacensis collected near Kokap (Menoreh Hills) and Bangarnegara district (on the Dieng Plateau) in Central Java (Pranoto, Ministry of Health, personal communication). The association between the steep forested hillside environment favored by An. maculatus and An. balabacensis, and the risk of malaria in the region point to these species as the principal vectors in the Menoreh Hill epidemic. Other potential (secondary) vectors occur in the region; however, Anopheles aconitus and Anopheles barbirostris are regarded as inefficient vectors that favor rice paddy habitats, and Anopheles sundaicus is a highly efficient vector of malaria occurring in abundance on the coast. As a result, these habitats below the Menoreh Hills and Dieng Plateau of Central Java remain largely free of malaria.

Human population. An estimated 770,000 people live in Purworejo. The district capital, located on the broad plain that composes the southern half of the district, contains 95,000 residents. Population statistics for the year 2000, based on a 1999 census, estimate that 414,000, 230,000, and 127,000 people live in hill, plain, and coastal regions, respectively. Most people in Purworejo work in support of the agriculture industry, living in villages or hamlets scattered across the pastoral landscape. Virtually all children routinely attend schools with structured curricula, and the population is almost entirely literate. A major transportation artery transects Purworejo district through the low plain, linking the commercially and culturally important city of Jogyakarta with virtually all points west below the Dieng Plateau.

Health care system. Residents of Purworejo district access medical care through a system of 25 health clinics and one hospital operated by the provincial government. Each subdistrict has one or two clinics, depending on the population. One or two physicians, a few nurses, and administrative personnel typically staff each clinic. Clinics located in the malarious subdistricts have laboratories with at least one functioning microscope and a designated, full-time microscopist. Most villages in the district have a full-time midwife and administrative assistant staffing a permanent health station. Villages without a station typically have a trained midwife resident to provide maternal and child health services from her home. The village health workers operate under the supervision of the clinic physician. This subsidized care system charges, on average, about $\$ .37$ (in U.S. currency) per visit, including medications. Patients with malaria are typically charged about $\$ .60$ (in U.S. currency) to cover the cost of diagnosis and antimalarial medications.

Malaria surveillance system. Malaria case detection in Purworejo occurs at the village level though malaria field workers and midwives at the health posts and at the health clinics. A force of approximately 100 field workers provided the backbone of malaria control activities in the district before the economic crisis of 1997. In 2000 this force had been pared to just 12. Field workers are experienced and trained in passive and active case detection as well as vector control. Village volunteers and schoolteachers supplemented the field workers, but this force typically received only 1 day of training in malaria case recognition and treatment. Field workers, village volunteers, midwives, and schoolteachers all provide data on malaria treatment to the health post or the health clinic, along with blood films for laboratory confirmation of the clinical diagnosis. Laboratory staff refers positive blood films to the district health laboratory for routine cross-check. Malaria cases described in this report were thus confirmed microscopically.

An increase in malaria cases often prompts active case detection efforts by clinic staff within areas with suspected active transmission. The total number of cases reported thus reflects both passive and active case detection strategies. This approach creates the potential for a detection bias (i.e., increasing numbers of cases tend to increase efforts at case detection). In Purworejo district, the annual blood examination rate (ABER; slides examined per 100 population) was relatively constant from 1986 to 1993 at about $14.0 \%$, ranging from a low of $10.4 \%$ in 1987 to a high of $17.4 \%$ in 1991 . After 1993, blood examination efforts became less stable. To control for the effect of sampling effort, API figures were standardized to the ABER (see below).

Data analysis. The district health office compiled monthly summaries of malaria at the village, subdistrict, and district levels. The government monitors population annually at these levels, and these estimates served as the denominators for the API estimates reported here. The ABER represents a measure of case detection vigor, and standardizing the API to ABER minimizes potential detection bias. We standardized the API for blood collection efforts as measured by the ABER using the method described by Roberts and others. ${ }^{20}$ A uniform ABER representing the mean rate over a period of stable case detection activity multiplied by the total population gave an adjusted rather than actual number of slides examined. The observed slide-positive rate was multiplied by the adjusted number of slides examined to yield the adjusted number of infections, and this was divided by the total population in that year to give a standardized API.

We devised a calculation to illustrate the change in risk of malaria normalized to case burden within a subunit of a defined larger area. In this instance, we normalized change in risk of malaria in subdistricts to the total case burden in Purworejo. The following calculation was used:

$$
\begin{aligned}
& \frac{\text { cases in the subdistrict in } 2000}{\text { cases in the subdistrict in } 1995} \\
& \times \frac{\text { cases in the subdistrict in } 2000}{\text { cases in the district in } 2000}
\end{aligned}
$$

Multiplying the ratio of slide-confirmed cases in 2000 to 1995 by the relative contribution of the 2000 cases to the total number of cases in the district provided a measure of the increase in malaria risk in a subdistrict normalized to the district case burden. This approach corrected the problem of exceedingly high rates of increase in subdistricts contributing relatively few total cases to the district case burden. We used the statistic to highlight subdistricts having both a rapid increase in malaria and contributing a relatively high proportion of the total case burden (i.e., subdistricts representing the core of the epidemic). We called this statistic the regionally normalized increase in risk.

\section{RESULTS}

Malaria in Central Java. Thirty-five districts compose Central Java Province. Figure 5 illustrates the number of slideconfirmed cases of malaria and the standardized API for Cen- 


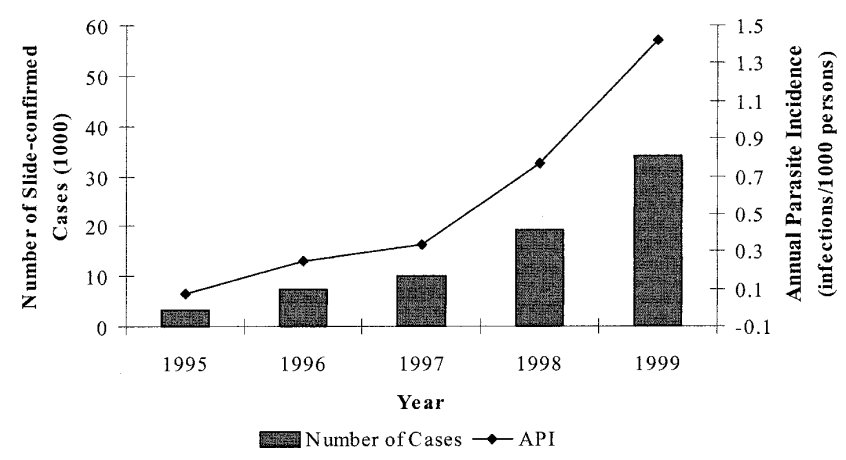

Figure 5. Malaria in Central Java, 1995 to 1999, according to slide-confirmed cases reported and an annual parasite incidence standardized to sampling effort (annual blood examination rate, see Materials and Methods). Data from the Ministry of Health, Republic of Indonesia.

tral Java from 1995 to 1999 . The ABER decreased from 2.58 in 1995 to 1.45 in 1999, and the API was accordingly standardized using the average ABER over the period. The standardized API increased 18-fold, from 0.08 in 1995 to 1.42 in 1999. In 1996, 16 districts reported malaria cases and six districts had more than 200 cases. Purworejo and Jepara districts accounted for $75 \%$ of all cases in the Central Java. By 1999 , 20 districts reported malaria; eight districts reported more than 200 cases. Purworejo accounted $60 \%$ of all malaria, whereas most of the remaining $40 \%$ of cases occurred among seven other districts.

Malaria in Purworejo. Figure 6 shows the number of slideconfirmed malaria cases and the standardized API in Purworejo from 1986 to 2000. Except for a modest increase in cases in 1993, between 1986 and 1997 the annual number of malaria cases in the subdistrict remained relatively stable at several thousand among the 700,000 residents (4.7 cases per 1,000 residents per year). In 1997, the district reported 3,468 slide-confirmed cases ( 4.6 cases per 1,000 residents). In 2000 that number increased to 34,280 cases (44.5 cases per 1,000 residents). The ABER in Purworejo remained relatively stable at $14 \%$ between 1986 and 1993 (range $=10-17 \%$ ). From 1994 to 1999, the ABER dropped as low as 4\% and peaked at $10 \%$. In 2000, the ABER reached $16 \%$. Using the standard adjustment for ABER, we calculated a standardized API for the year 2000 of 38 cases per 1,000 residents. As was typical for most of Java, the ratio of Plasmodium falciparum to Plasmodium vivax for the epidemic in Purworejo has been approximately 1:1.

Figure 7A and B illustrates the relationship between steep, forested terrain and the risk of malaria in Purworejo district. These panels demonstrate an increase in the regionally normalized risk almost entirely within areas dominated by steep, forested terrain. The subdistrict of Bagelen in the southeast area of the district, although dominated by flatland (see Figure 7A) contains steep hills at its northern tier where virtually all malaria cases occurred.

Malaria control activities. Treatment of uncomplicated malaria in Purworejo follows guidelines set forth by the Ministry of Health. Chloroquine ( $25 \mathrm{mg} / \mathrm{kg}$ every 48 hours) is the first line of therapy. It is augmented with $15 \mathrm{mg}$ primaquine base daily for 5 days with $P$. vivax for prevention of relapse and with a single dose of $45 \mathrm{mg}$ primaquine base with $P$. falciparum as a gametocytocide to block transmission. Recurrent

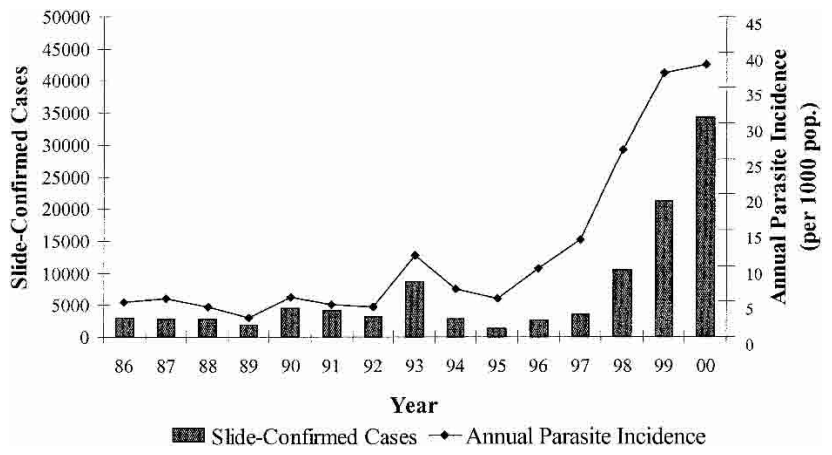

Figure 6. Malaria in Purworejo district, 1986 to 2000. Data from the Purworejo District Health Office. Annual parasite incidence standardized to sampling effort (annual blood examination rate, see Materials and Methods).

parasitemia (within 1 month of treatment) is treated with a single dose of pyrimethamine/sulfadoxine $(1,500 \mathrm{mg}$ sulfadoxine plus $75 \mathrm{mg}$ pyrimethamine) and primaquine as described previously. The third line of treatment is oral quinine. As throughout Indonesia, the District Health Service provides stocks of these drugs to all clinics in Purworejo. The district government obtains the drugs from the provincial government as needed. The supply of antimalarials was not an issue throughout the 1990s. There were adequate stocks during visits in July 2000, and no health service officer could cite drug supply problems in the past 10 years.

Indoor residual spraying (IRS) has been the foundation of vector control activities in Purworejo. Larvicidal or species sanitation activities have not proven practical. DDT was the primary instrument of IRS activity in the district from 1953 until 1989. IRS teams used fenitrothion from 1986 to 1993, and bendiocarb had been used exclusively since 1993. The District Health Service conducted vector control activities with regulatory and technical guidance from the Ministry of Health. Clinics applied pesticides for malaria control only
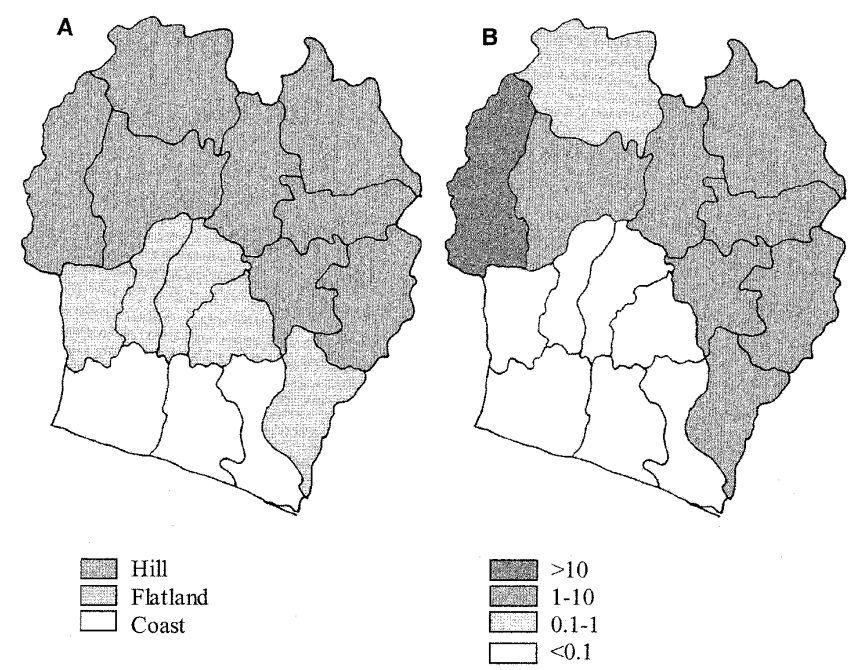

FIGURE 7. A. Map of Purworejo district showing subdistrict borders. Each subdistrict is classified as being predominantly coastal, flatland, or hill habitat. B. Map of Purworejo district showing subdistrict borders illustrates the classification of each subdistrict according to the regionally normalized change in API between 1995 and 2000. 


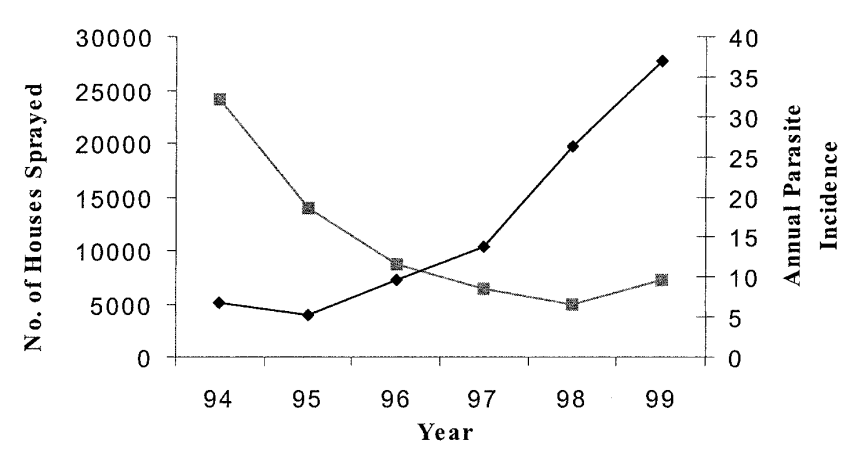

$\rightarrow$ No. of houses sprayed $\multimap-$ Adjusted API

FIGURE 8. Declining indoor residual spraying activity and the standardized API for Purworejo district between 1994 and 1999 (Purworejo District Health Office).

with on-the-scene consultation from trained Ministry of Health officers assigned to the region. The District Health Service received insecticide stocks from the provincial government as available. The limiting factor in household coverage was availability of stocks, and this reflects both the ability of the provincial government to purchase the insecticide and a diminished emphasis on this activity as a core malaria control activity. Figure 8 illustrates the declining coverage of households sprayed with bendiocarb between 1994 and 1999 in relation to the increasing standardized API in Purworejo over the same period. The decline in spraying activities began well before the economic crisis of 1997.

Economic factors. Funds from a single source, the People's Health Service Fund (Peningkatan Pelayanan Kesehatan Masyrakat [ PPKM]) supported virtually all aspects of health care in Purworejo district. The fund originates at the national government level in Jakarta and reaches the Purworejo district government through Central Java provincial health agencies in Semarang. The fund supports health clinic operations and administration, immunization programs, nutrition programs, maternal and child health programs, and communicable disease control. Malaria activities supported by PPKM consist of field staff salaries, contract laborer wages to conduct IRS, larviciding and biological control activities, purchase of microscope slides, equipment repair, and transportation for vector control and disease survey activities. Patient revenue from clinic visits is available for malaria control activities at the discretion of the health clinic physician.

Figure 9 shows the annual PPKM budget for public health in Purworejo district and the proportion of that used to support malaria control. The total PPKM budget fell from approximately $\$ 150,000$ (U.S. currency) in 1997 to $\$ 20,000$ in 1999. This decrease reflects the impact of the East Asian economic crisis that erupted in 1997. The Indonesian currency lost $80 \%$ of its value relative to the U.S. dollar. For the fiscal year April 1999 to March 2000, the PPKM funds available for malaria control in the district was less than $\$ 4,000$. Vector control activities were eliminated.

\section{DISCUSSION}

An epidemic of malaria in the forested steep hills of Purworejo in Central Java demonstrates the threat this disease

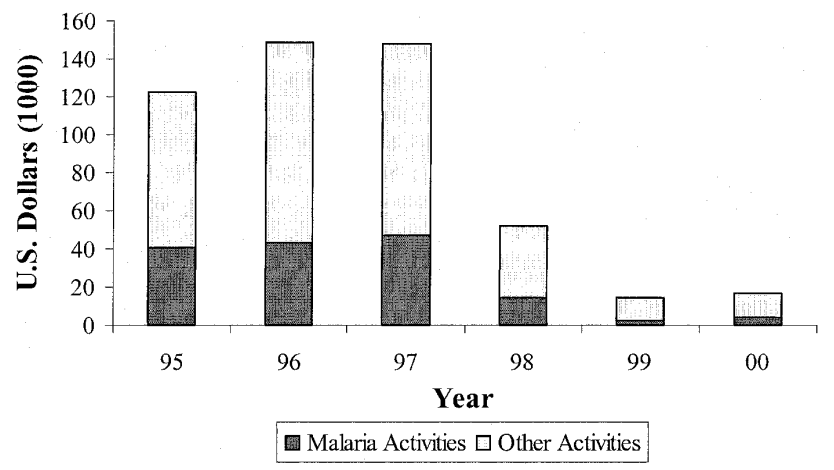

FIGURE 9. Proportion of total public health budget used for malaria surveillance and control between 1995 and 2000 in Purworejo district (Purworejo District Health Office). Reported budgets in Indonesian rupiah were converted to U.S. dollars using the mean exchange rate for the given year.

poses for the 130 million people living on the island. At risk are the strides made against malaria on Java, beginning with the successful species sanitation campaigns against $A$. sundaicus on the north coast in the $1930 \mathrm{~s}^{21}$ and ending with the DDT and dieldrin spraying campaigns of the 1950s and 1960s. ${ }^{15}$ Parasites resistant to available antimalarials, economic conditions that cripple vector control and a moratorium on DDT leave few practical tools with which to attack this epidemic and the threat of encroaching endemic malaria on the island.

Competent anopheline vectors of malaria abound in most habitats on Java (see Figure 4). Except for sporadic outbreaks linked to infected travelers, the cycle of transmission in coastal marsh and lagoon, rice paddy, and most hillside habitats on Java had been broken in the 1950s. However, six districts in Central Java and the special area of Yogyakarta maintained chronic hypoendemicity: Purworejo, Banjarnegara, Wonosobo, Pekalongan, Jepara, and Kulonprogo (API typically $>1.0$ ). With the exception of Jepara on the north coast, malaria in the other five districts may be described as essentially limited to hillside habitats. The cycle of transmission in A. maculatus and A. balabacensis in these areas appears to have persisted in the face of efforts that proved almost completely successful in coastal and paddy habitats.

Several important factors may help explain the persistence of endemic malaria in hillside communities. The relative difficulty of removing breeding sites and attacking the larvae of A. maculatus and $A$. balabacensis almost certainly has played a role. Unlike lagoons and rice paddies, breeding sites for these mosquitoes are widely scattered throughout hillside habitats. Ubiquitous rocky streams down steep, forested slopes offer a profusion of ideal breeding sites. A single stream of just a few kilometers swells with rainfall and rapidly recedes, leaving thousands of small, isolated pools. Many hundreds of such streams occur in the hills of Purworejo district. Neither draining or flushing the pools nor chemically attacking the larvae are feasible.

Social and economic factors also help explain the persistence of hillside malaria. Hillside residents live in traditional Javanese houses of wood planks and bamboo, whereas people in the flatlands tend to use cement or cinderblock construction for homes. Poor or nonexistent roads limit access to health care as well as the economic means to pay for care. 
Flatland residents have ready access to transportation and tend to be wealthier. Population density is much higher in the hills compared with the coastal or paddy habitats. Vast stretches of rice paddy separate communities, whereas the tree crops of the hills allow people to live virtually anywhere. In summary, people living in the hills tend to be more exposed to biting anophelines, live closer to neighbors, and be less wealthy and mobile than residents of the coastal and paddy habitats. It may be reasonable to suppose a scenario in which hillside residents living in homes readily accessible to relatively abundant vectors are less likely to obtain early and effective treatment and more likely to contribute to the infection of their neighbors.

Indoor spraying of residual insecticide apparently played a key role in controlling malaria transmission in the hillside communities of Purworejo. Figure 8 illustrates the curtailment in spraying activity beginning in 1994 coinciding with earliest signs of epidemic in 1996. The economic crisis of 1997 (see Figure 9) precluded resumption of normal spraying activities. This appears to have been the key factor driving the epidemic. Given the plausible scenario of abundant vectors among relatively dense communities of homes accessible to feeding mosquitoes, the apparent importance of indoor residual spraying may be appreciated.

The epidemic of malaria in the Menoreh Hills of Central Java corroborates evidence from many other sources suggesting a broad deterioration of the malaria situation around the globe. The predominant force driving resurgent malaria on Java appears to be the deterioration of the capacity to apply residual insecticides. This interpretation is consistent with the analysis of malaria incidence in South America reported by Roberts and others. ${ }^{20}$ We believe chemotherapy as the primary instrument of malaria control is unlikely to succeed in Java, where diagnosis and treatment are marginal for the time being. Unlike holoendemic Africa, most infections in Java carry a relatively high risk of disease and death. It seems unreasonable to construct an instrument of malaria control that defers intervention to the onset of illness and realization of that risk. The record of success with residual insecticides on Java points to that strategy as the rational choice of a primary intervention. In the absence of effective interventions, endemic malaria may reclaim the island of Java in the coming few years.

Acknowledgments: The authors gratefully acknowledge Dr. Mark Lacy and Mr. Soeroto Atmosoedjono of NAMRU-2, Mr. John Neatherlin of Emory University, Dr. Sekartuti of the Ministry of Health, and the many people in the Purworejo District Health Service for their assistance in gathering the information presented here.

Disclaimer: The views and opinions are those of the authors and do not purport to represent those of the U.S. Navy or Department of Defense.

Financial support: This work was supported by the U.S. Department of Defense Global Emerging Infections Surveillance Program.
Reprint requests: Commanding Officer, U.S. Naval Medical Research Unit \#2, American Embassy Jakarta, FPO AP 96520;nh8132 USA, attention of the Publications Office.

\section{REFERENCES}

1. Campbell CC, 1997. Malaria: an emerging and re-emerging global plague. FEMS Immunol Med Microbiol 18: 325-331.

2. Kondrachine AV, Trigg PI, 1997. Global overview of malaria. Indian J Med Res 106: 39-52.

3. National Academy of Sciences, 1996. Vaccines against malaria: Hope in a gathering storm. Washington, DC: National Academy Press.

4. Krogstad DJ, 1996. Malaria as a reemerging disease. Epidemiol Rev 18: 77-89.

5. Baird JK, 2000. Resurgent malaria at the millennium. Drugs 59: 719-743.

6. World Health Organization, 1997. World malaria situation in 1994: Part II. The Americas. Wkly Epidemiol Rec 72: 277-284

7. World Health Organization, 1997. World malaria situation in 1994: Part III. Wkly Epidemiol Rec 72: 285-290.

8. Feighner BH, Pak SI, Novakoski WL, Kelsey LL, Strickman D, 1998. Reemergence of malaria in the Republic of Korea. Emerg Infect Dis 4: 295-297.

9. Bangs MJ, Subianto DB, 1999. El niño and associated outbreaks of severe malaria in highland populations in Irian Jaya, Indonesia: a review and epidemiological perspective. Southeast Asian J Trop Med Public Health 30: 608-619.

10. Malakooti MA, Biomndo K, Shanks GD, 1998. Reemergence of epidemic malaria in the highlands of Western Kenya. Emerg Infect Dis 4: 671-676.

11. Zucker JR, 1996. Changing patterns of autochthonous malaria transmission in the United States: a review of recent outbreaks. Emerg Infect Dis 2: 37-43.

12. Abeyasekere S, 1989. Jakarta: A history (rev ed). Singapore: Oxford University Press.

13. Walch EW, Soesilo R, 1935. Malaria control in the Netherlands Indies. Mededeelingen van Dienst der Volksgezondheid in Nederlandsch-Indie 24: 86-94.

14. Van Thiel PH, Winoto RMP, 1951. Control of hyperendemic malaria on Java caused by Anopheles sundaicus by DDT house spraying. Trop Geogr Med 7: 164-181.

15. Atmosoedjono S, 1990. Malaria control in Indonesia since World War II. Wageningen Agricult Univ Papers 90: 141-154.

16. Arbani PR, 1992. Malaria control program in Indonesia. Salazar NP, Chongsuphajaisiddhi TC, Harinasuta T, Karbwang J, eds. Advanced Knowledge on Malaria in Southeast Asia 23 (Suppl 4): 29-38.

17. Baird JK, Sismadi P, Masbar S, Ramzan A, Purnomo BW, Sekartuti, Tjitra E, Rumoko BW, Arbani PR, 1996. A focus of endemic malaria in Central Java. Am J Trop Med Hyg 54: 98-104.

18. Sundararaman S, Soeroto RM, Siran M, 1957. Vectors of malaria in mid-Java. Indian J Malariol 11: 321-338.

19. Takken W, Knols BJG, 1990. A taxonomic and bionomic review of the malaria vectors of Indonesia. Wageningen Agricult Univ Papers 90: 9-62.

20. Roberts DR, Laughlin LL, Hsheih P, Legters LJ, 1997. DDT, global strategies, and a malaria control crisis in South America. Emerg Infect Dis 3: 295-302.

21. Snellen WB, 1990. Success and failure of malaria control through species sanitation: some practical examples. Wageningen Agricult Univ Papers 90: 81-127. 